\title{
The Role of Bhabinkamtibmas in Supporting Motor Vehicle Tax Arrears Collection During the Covid-19 Pandemic
}

\author{
Nyi Ayu Fitria Facha*) and Achmad Sulchan*)
}

\author{
*) Police Academy Youth Company Commander, E-mail: \\ nyiayu mh36@std.unissula.ac.id \\ ${ }^{* *}$ Faculty of Law, Universitas Islam Sultan Agung (UNISSULA) Semarang
}

\begin{abstract}
.
This study aims to analyze the role of Bhabinkamtibmas in supporting the collection of motor vehicle tax arrears during the covid-19 pandemic in the Demak police jurisdiction and the obstacles to implementing the role of Bhabinkamtibmas in supporting the collection of motor vehicle tax arrears during the covid-19 pandemic in the Demak police jurisdiction and the solutions. The approach method is sociological juridical; analytical descriptive research specifications; data sources are primary data and secondary data; data collection methods through field studies and literature studies; while the data analysis method used qualitative analysis. As an analytical tool, role theory, legal effectiveness theory and benefit theory are used. The results of the study show that the role of Bhabinkamtibmas in supporting the collection of motor vehicle tax arrears in the jurisdiction of the Demak police station is to submit a motor vehicle tax bill to motorized vehicle taxpayers. This role is effective in increasing the realization of PKB revenue in the Demak Regency. The obstacles to implementing the role of Bhabinkamtibmas in supporting the collection of motor vehicle tax arrears come from internal and external factors.
\end{abstract}

Keywords: Billing; Order; Security; Supervising; Tax; Vehicle.

\section{Introduction}

The regional autonomy system requires various regions to look for alternative sources of revenue that can be used to finance regional expenditures and expenditures, one of which comes from the tax sector. Taxes are people's contributions to the state treasury (switching from the private sector to the government sector) based on the law (can be enforced) without receiving a lead service (tegen prestatie) which can be directly appointed to finance public expenditures and which are used as a means of preventing or encouraging public expenditures achieve goals that exist outside the financial sector. ${ }^{1}$ One of the regional taxes managed by the regional government is the Motor Vehicle Tax (PKB).

In Central Java Province, PKB is a tax sector that is very dominant in contributing to Regional Original Income (PAD). This can be seen from the PKB data receipts in 2019 which reached $103 \%$ or IDR 4.6 trillion from the target of IDR 4.5 trillion. $^{2}$ On the other hand, the low awareness of the public in paying taxes

\footnotetext{
1 Rochmat Soemitro in Suparnyo, (2012), Hukum Pajak Suatu Sketsa Asas, Semarang: Penerbit Pustaka Magister, p. 31

${ }^{2}$ Begini Syarat Memutihkan pajak Kendaraan, (https://news.ddtc.co.id, accessed on 20 May 2021).
} 
is an obstacle. This is evidenced by data that there are PKP arrears in 2019 reaching $\mathrm{Rp} 450$ billion. $^{3}$

In Demak Regency alone, more than 80 percent of total regional revenue comes from taxes, one of which is the Motor Vehicle Tax. However, since the entry into force of the Covid-19 pandemic, there has been a decline and arrears, especially the PKB, which amounted to 14 billion rupiah. Based on the above conditions, the Regional Revenue Management Unit (UPPD) of Demak Regency cooperates with the Demak Resort Police (Polres) to optimize the payment and collection of motor vehicle tax debts. Through this collaboration, it is hoped that it will increase the awareness of vehicle owners to fulfill their tax obligation. ${ }^{4}$

The partnership program with the Demak Police is given the name "Bali Jaran Polres Demak", which means Bhabinkamtibmas Cares about Vehicle Taxes. The existence of Bhabinkamtibmas is very vital in providing police services or assistance considering that there are no police posts in the village or in the villages. ${ }^{5}$ Bhabinkamtibmas is the spearhead of the police to be able to touch the community on the smallest line within the village. ${ }^{6}$ Bhabinkamtibmas is also the administrator of Polmas in the village. ${ }^{7}$ The goal to be achieved in the Bhabinkamtibmas activity is the realization of a stable and dynamic security and security situation in the context of securing and succeeding in national development. ${ }^{8}$ Therefore, through the duties and functions of the Bhabinkamtibmas Polres Demak, it is hoped that it can raise awareness of taxpayers to pay their tax arrears, so as to increase regional revenues.

Bhabinkamtibmas as Polri personnel who go down to the village/kelurahan level with the task and function of partnering with the community, of course, their role is very much needed in breaking the chain of spreading the Covid-19 virus. ${ }^{9}$ In carrying out their role, Bhabinkamtibmas officers only help deliver tax certificates. In this case, if the community has not paid the motor vehicle tax, Babinkamtibmas is asked for assistance in conveying it to the community at the village level door to door. ${ }^{10}$

\footnotetext{
${ }^{3}$ Jateng Bebaskan Denda Pajak dan Balik nama Kendaraan, (https://semarang.bisnis.com, accessed on 20 May 2021).

${ }^{4}$ Tagih Pajak Rp14 Miliar, Pemkab Ini Gandeng Polisi, (https://news.ddtc.co.id, accessed on 20 May 2021).

${ }^{5}$ Antonius Iwan Murdianto, Implementation Babinkamtibmas Completion Of Problems In Regency, Jurnal Daulat Hukum Volume 1 No. 2 June 2018, url : http://jurnal.unissula.ac.id/index.php/RH/article/view/3284/2419, p.248

${ }^{6}$ Maisa and Irmawty Ambo, Optimalisasi Bhabinkamtibms dalam Rangka Harkamtibmas di Wilayah Hukum Polres Palu, Kalibbirang Law Journal, Volume 1, Nomor 2, August 2019, p.2

7 Surajab, "Community Policing Strategy (Polmas) In The Implementation Of Bhabinkamtibmas Tasks as A Radical Detection Basis", Jurnal Daulat Hukum, Volume 3 Issue 3, September 2020, url : http://jurnal.unissula.ac.id, p.330.

${ }^{8}$ Ramadhan N, "Strategi Bhabinkamtibmas Dalam Upaya Optimalisasi Penerapan Program Door To Door System (Studi Kasus Polsek Menganti)", Airlangga Development Journal, Volume 2 Nomor 2, 2018, p.133

${ }^{9}$ Fania Mutiara Savitri, “Optimalisasi Strategi Polri Dalam Pelaksanaan Tugas Bhabinkamtibmas Guna Mendukung Penerapan Protokol Kesehatan Selama Pandemi Covid-19 Di Polda Jateng", Jurnal Litbang Polri, Edition January 2021, p.71

${ }^{10}$ https://news.ddtc.co.id, Loc.Cit.
} 
Bhabinkamtibmas in carrying out its role must continue to apply health protocols, so that the spread of Covid-19 does not continue to increase. The implementation of health protocols is very important, as part of the task of the National Police in realizing public security and order that is expected together. Bhabikamtibmas in dealing with the community is faced with a great responsibility. Gaining the trust of the community is difficult to obtain, because it requires a process, especially communication and social contact, time and the will of each police officer. ${ }^{11}$

In practice, there are several Bhabinkamtibmas personnel who do not have adequate insight and knowledge regarding the implementation of their duties, in supporting the collection of PKB arrears for taxpayers. In addition, other problems are the difficulty of finding the address in question, the taxpayer has changed address or the taxpayer does not want to leave the house to meet the officer. On the basis of the above description, this study aims to analyze the role of Bhabinkamtibmas in supporting the collection of motor vehicle tax arrears during the Covid-19 pandemic in the Demak Police jurisdiction and to analyze the obstacles to implementing Bhabinkamtibmas' role in supporting the collection of motor vehicle tax arrears during the Covid-19 pandemic in the region. Demak Police Law and its solutions.

\section{Research Methods}

The approach method used in this thesis is a sociological juridical approach, which is an approach method that is carried out by reviewing existing legal rules as well as reviewing how they are implemented in society. This is because there is a close relationship between juridical and sociological factors. ${ }^{12}$ The research specification is descriptive analytical. Sources and types of data used are primary data and secondary data. The data collection method is carried out through field studies and literature studies, and the method of analysis is qualitative analysis.

\section{Result and Discussion}

\subsection{The Role of Bhabinkamtibmas in Supporting the Collection of Motor Vehicle Tax Arrears During the Covid-19 Pandemic in the Legal Territory of the Demak Police}

The role of Bhabinkamtibmas in supporting the collection of motorized vehicle tax arrears during the Covid-19 pandemic in the jurisdiction of the Demak Police is to serve as an introduction to invoices for motor vehicle tax arrears. If the community has not paid taxes, then Babinkamtibmas is asked for assistance in conveying it to community members at the village level who conduct through door to door activities. The tax invoice is submitted to the taxpayer who has not paid the motor vehicle tax by the Bhabinkamtibmas officer. Bhabinkamtibmas only delivered a letter from Samsat, because the police were not authorized to collect

\footnotetext{
11 Fania Mutiara Savitri, Op. Cit.

12 Ronny Hanitijo Soemitro, 1998, Metodologi Penelitian Hukum, Jakarta : Ghalia, p.34.
} 
vehicle taxes. Thus, Bhabinkamtibmas officers are not allowed to accept money or deposits related to motor vehicle taxes. Bhabinkamtibmas also conveyed security and security messages such as the message for peaceful elections, ${ }^{13}$

Bhabinkamtibmas will provide SPKPPKB to taxpayers who are in arrears and also accompanied by a Receipt of Notification of Motor Vehicle Tax Payment Obligations, in which there is information regarding the status of the vehicle. Bhabinkamtibmas will then verify the status of the vehicle in accordance with the conditions encountered in the field. When Bhabinkamtibmas conveys SPKPPKB to taxpayers it meets, Bhabinkamtibmas also gives messages or educates taxpayers who are in arrears to comply with paying taxes. If you do not pay taxes, you will be able to get a ticket when the Traffic Traffic Unit conducts a raid. The delivery of SPKPPKB by Bhabinkamtibmas along with messages to taxpayers who are in arrears will give the impression that even though those who come are members of the Police, they are familiar, not scary, ${ }^{14}$

The results showed that after the role of Bhabinkamtibmas the realization of motor vehicle tax arrears in 2019 was IDR 7,154,520,805.00, in 2020 it was $8,119,203,205.00$ and in 2021 until October it was 6,976,667,026.00. . The data above illustrates that there is an increase in receipt of motor vehicle tax arrears from 2019 to October 2021. The above data illustrates that Bhabinkamtibmas' involvement in supporting the task of collecting motor vehicle tax arrears contributed to the increase in income for motor vehicle tax arrears.

Based on the description above, it can be seen that the role of Bhabinkamtibmas in supporting the task of collecting motor vehicle tax arrears is as an introduction to tax invoices, but does not collect taxes and does not receive tax deposits from motorized vehicle taxpayers who are in arrears. In carrying out this role, Bhabinkamtibmas gives a message to every taxpayer to obey the law and be willing to pay motor vehicle taxes that are in arrears. This is in line with the task of Bhabinkamtibmas which is to provide guidance to community members who are their responsibility to be able to increase community participation, legal awareness and community compliance with applicable laws and regulations.

Judging from role theory ${ }^{15}$, Bhabinkamtibmas has carried out the ideal role, in this case Bhabinkamtibmas has carried out its duties as an introduction to tax invoices accompanied by giving messages to taxpayers to comply with laws and regulations, namely the obligation to pay taxes while remaining familiar. In this case, Bhabinkamtibmas acts as a protector for the community in order to create order and security which has the ultimate goal of community welfare. With the Bhabinkamtibmas providing guidance to motorized vehicle taxpayers who are in arrears, it is hoped that these taxpayers will then make tax payments which will ultimately provide welfare to the community.

The role of Bhabinkamtibmas in supporting the task of collecting motor vehicle tax arrears is very effective in increasing motor vehicle tax revenues in Demak Regency. This is in line with the theory of legal effectiveness which states

\footnotetext{
13 Results of an interview with AKP Agus Subrojo as the Sayung Police Chief, on November 17, 2021.

${ }^{14}$ Results of Interview with Mrs. Rukminingtyas Utami, as Head of Sub-section of TU of the Regional Revenue Management Unit of Demak Regency, November 18, 2021

${ }^{15}$ Soerjono Soekanto, 2009, Sosiologi Suatu Pengantar, Jakarta : Rajawali Pers, p. 212.
} 
that legal effectiveness is the conformity between what is regulated in the law of implementation. ${ }^{16}$ In this case, the effectiveness of the law is related to the business factor of instilling law in society, namely with the existence of Bhabinkamtibmas which gives a legal message to the community of motorized vehicle taxpayers, the taxpayer will be moved to pay off his tax arrears.

The effectiveness of the Bhabinkamtibmas role in supporting the task of collecting motor vehicle tax arrears is influenced by the following factors:

- The legal rules or regulations themselves, the implementation of Bhabinkambtimas' role in supporting the task of collecting motor vehicle tax arrears are in line with the objectives of Bhabinkamtibmas as contained in Article 2 of the National Police Regulation Number 7 of 2021 which states that Bhabinkamtibmas aims to increase public participation, public legal awareness, and the obedience of citizens to laws and regulations. The collection of motor vehicle tax arrears to taxpayers is based on the PDRD Law, specifically for the Demak Regency area, supported by the Central Java Regional Regulation Number 2 of 2011 concerning Regional Taxes for Central Java Province. In addition, the Central Java Regional Government's policy regarding the exemption of motor vehicle tax penalties is a supporting factor in collecting tax arrears.

- The officer or law enforcement officer, in this case Bhabinkamtibmas only acts as an introduction to the motor vehicle tax bill, verifying the status of the motorized vehicle in question as well as giving a message to the motorized vehicle taxpayer to pay off the tax arrears. The public is given instructions that if the tax arrears are not paid, then if there is a raid, a ticket can be imposed. The messages conveyed by Bhabinkamtibmas turned out to be effective, so that motorized vehicle taxpayers were willing to pay tax arrears.

- Facilities or facilities factor, in carrying out its role Bhabinamtibmas requires transportation facilities to support its activities of making home visits to motorized vehicle taxpayers. In this case, the UPPD of Demak Regency has provided a replacement for transportation of IDR 10,000, - or more based on the provisions of the budget ceiling that has been set for each SPKPPKB sheet to Bhabinkamtibmas for the return of the SPKPPKB that has been verified by the taxpayer.

- Community, public awareness that can be fostered by regular legal counseling. In this case, Bhabinkamtibmas provides guidance to motorized vehicle taxpayers regarding taxpayer compliance to pay motor vehicle tax before it is due. With this guidance, the community will eventually make payment of motor vehicle tax arrears.

The role of Bhabinkamtibmas in supporting the task of collecting motor vehicle tax arrears is also in accordance with the benefit theory, where the main purpose of benefit is to preserve the harm and maintain the benefits. ${ }^{17}$ With the role of Bhabinkamtibmas who conducts visits and provides guidance to taxpayers

\footnotetext{
${ }^{16}$ Salim H.S and Erlis Septiana Nurbani, 2013, Penerapan Teori Hukum Pada Tesis dan Disertasi, First Edition, Jakarta : Rajawali Press, p. 375

${ }^{17}$ Rahmad Syafi'i, 1999, Ilmu Ushul Fiqh, Bandung: CV Pustaka Setia, p. 117
} 
who are in arrears in paying taxes, it will eventually make taxpayers aware so that taxpayers are willing to pay motor vehicle tax arrears. Tax payments made by these taxpayers will ultimately contribute to the increase in local revenue of Demak Regency. The results of the motor vehicle tax receipts can ultimately benefit the people in the Demak Regency area ${ }^{18}$.

\subsection{Barriers to the Implementation of the Role of Bhabinkamtibmas in Supporting the Collection of Motor Vehicle Tax Arrears During the Covid-19 Pandemic in the Legal Territory of the Demak Police and their Solutions}

The obstacles in the implementation of this role are as follows:

- Lack of knowledge from Bhabinkamtimas officers; There are still some Bhabinkamtibmas personnel who do not have adequate insight and knowledge regarding the implementation of their duties, in supporting the collection of arrears of Motor Vehicle Tax for taxpayers. ${ }^{19}$ The solution to overcome these obstacles is in carrying out the task of collecting Motor Vehicle Tax arrears, Bhabinkamtibmas personnel are given insight and knowledge about the implementation of their duties, so that they can provide complete information when meeting taxpayers in debt.

- Bhabinkamtibmas officers did not fill out the complete report; There are still Bhabinkamtibmas personnel who do not fill out a complete task report, related to the collection of arrears of Motor Vehicle Taxes to taxpayers. ${ }^{20}$ The solution to overcome these obstacles is that the UPPD of Demak Regency asks the Police Chief to give instructions to Bhabinkamtibmas personnel to complete a complete task report, related to the collection of arrears of Motor Vehicle Taxes to the mandatory.

- Bhabinkamtimas is late in reporting; Bhabinkamtibmas officers are given a period of two weeks to make a report or return the SPKPPKB to the UPPD of Demak Regency. However, there are times when the Bhabinkamtibmas is late in providing reports. There are several reasons why Bhainkamtibmas is late in providing reports, for example remote locations, difficulty meeting taxpayers. ${ }^{21}$ The solution to overcome these obstacles is that the UPPD of Demak Regency has asked each Kapolsek to hold a meeting to motivate Bhabinkamtibmas officers to be on time in providing reports, so that reporting does not go back.

- The house visited by Bhabinkamtibmas officers is empty or has changed address; Sometimes the taxpayers visited by Bhabinkamtibmas are not at home, there are even houses that are empty or uninhabited because the owner of the house has changed addresses, and the new address is not even known. This resulted in the SPKPPKB not being conveyed to the intended motor vehicle

\footnotetext{
18 Ong Argo Victoria \& Myska. 2021. Doctor's Constributions in Transportation Monitoring During COVID-19 Pandemic. KnE Social Sciences, Dubai-Uni Emirates Arab (UEA), 5(1), 598-618. https://doi.org/10.18502/kss.v5i1.8317

${ }^{19}$ Results of an interview with AKP Agus Subrojo as the Sayung Police Chief, on November 17, 2021.

${ }^{20}$ Results of Interview with Mrs. Rukminingtyas Utami, as Head of Sub-section of TU of the Regional Revenue Management Unit of Demak Regency, November 18, 2021

21 Ibid.
} 
taxpayer. The solution to overcome these obstacles is to ask for information from the head of the local RT regarding the whereabouts of the taxpayer concerned. Likewise, if the transfer of the motorized vehicle taxpayer is not known, then Bhabinkamtibmas will still ask for information from the Head of the RT stating that the person concerned has changed addresses and his whereabouts are unknown.

- The host is not willing to meet the Bhabinkamtibmas officer; There are some taxpayers who deliberately do not want to meet the Bhabinkamtibmas officer when the officer comes to deliver the tax bill. For this reason, the Bhabinkamtibmas officer was unable to submit a tax invoice to the taxpayer, so in the end the tax invoice was returned to the UPPD of Demak Regency even though it had not been submitted to the motorized vehicle taxpayer concerned. ${ }^{22}$

- There is a Covid-19 pandemic; Bhabinkamtimas' involvement in supporting the collection of motor vehicle tax arrears stopped after the Covid-19 pandemic. This is because there is no order from the center to collect motor vehicle tax arrears. ${ }^{23}$ The solution to overcome these obstacles is that Bhabinkamtimbas continues to provide socialization regarding compliance with paying motor vehicle taxes.

\section{Clossing}

The role of Bhabinkamtibmas in supporting the collection of motor vehicle tax arrears in the jurisdiction of the Demak Police is to submit a motor vehicle tax invoice to the motorized vehicle taxpayer. This role is effective in increasing the realization of PKB income in Demak Regency. The obstacles to the implementation of Bhabinkamtibmas' role in supporting the collection of motor vehicle tax arrears come from internal and external factors. For this reason, it is necessary to provide education and training for Bhabinkamtibmas personnel, especially in communication techniques, partnership patterns to support the implementation of their role in supporting the collection of motor vehicle tax arrears.

\section{References}

\section{Journals:}

[1] Antonius Iwan Murdianto, "Implementation Babinkamtibmas Completion of Problems In Regency", Jurnal Daulat Hukum Volume 1 No. 2 June 2018, url : http://jurnal.unissula.ac.id/index.php/RH/article/view/3284/2419

[2] Fania Mutiara Savitri, "Optimalisasi Strategi Polri Dalam Pelaksanaan Tugas Bhabinkamtibmas Guna Mendukung Penerapan Protokol Kesehatan Selama Pandemi Covid-19 Di Polda Jateng", Jurnal Litbang Polri, Edition January 2021.

\footnotetext{
22 Results of an interview with AIPDA Bayu Apriyadi, Bhabinkamtibmas Batursari Mranggen Village, Demak, 18 November 2021

${ }^{23}$ Ibid.
} 
[3] Maisa and Irmawty Ambo, "Optimalisasi Bhabinkamtibms dalam Rangka Harkamtibmas di Wilayah Hukum Polres Palu", Kalibbirang Law Journal, Volume 1, Nomor 2, August 2019.

[4] Ong Argo Victoria \& Myska. 2021. “Doctor's Constributions in Transportation Monitoring During COVID-19 Pandemic", KnE Social Sciences, Dubai-Uni Emirates Arab (UEA), 5(1), 598-618. https://doi.org/10.18502/kss.v5i1.8317

[5] Ramadhan N, "Strategi Bhabinkamtibmas Dalam Upaya Optimalisasi Penerapan Program Door To Door System (Studi Kasus Polsek Menganti)", Airlangga Development Journal, Volume 2 Nomor 2, 2018.

[6] Surajab, "Community Policing Strategy (Polmas) In The Implementation of Bhabinkamtibmas Tasks as A Radical Detection Basis", Jurnal Daulat Hukum, Volume 3 Issue 3, September 2020, url : http://jurnal.unissula.ac.id.

\section{Books:}

[1] Rahmad Syafi'i, (1999), Ilmu Ushul Fiqh, Bandung: CV Pustaka Setia

[2] Rochmat Soemitro in Suparnyo, (2012), Hukum Pajak Suatu Sketsa Asas, Semarang: Penerbit Pustaka Magister

[3] Ronny Hanitijo Soemitro, (1998), Metodologi Penelitian Hukum, Jakarta : Ghalia

[4] Salim H.S and Erlis Septiana Nurbani, (2013), Penerapan Teori Hukum Pada Tesis dan Disertasi, First Edition, Jakarta : Rajawali Press

[5] Soerjono Soekanto, (2009), Sosiologi Suatu Pengantar, Jakarta : Rajawali Pers.

\section{Regulations:}

[1] Act No. 2 of 2002 concerning the Indonesian National Police. Jakarta, 2002

[2] Act No. 28 of 2009 concerning Regional Taxes and Levies

[3] Regional Regulation of Central Java Province Number 2 of 2011 concerning Regional Taxes of Central Java Province.

\section{Internet:}

[1] Begini Syarat Memutihkan pajak Kendaraan, (https://news.ddtc.co.id, accessed on 20 May 2021).

[2] Jateng Bebaskan Denda Pajak dan Balik nama Kendaraan, (https://semarang.bisnis.com, accessed on 20 May 2021).

[3] Tagih Pajak Rp14 Miliar, Pemkab Ini Gandeng Polisi, (https://news.ddtc.co.id, accessed on 20 May 2021). 